\title{
Factors Influencing Information Disclosure by Malaysian State Islamic Religious Councils: Evidence from Interviews
}

\author{
Rosnia Masruki, Khaled Hussainey, and DoaaAly
}

\begin{abstract}
This paper aims to identify factors that influence the expectations of a wide range of stakeholders on the information disclosure in the SIRC annual reports, employing semi-structured interviews. The majority of interviewees perceived accounting standards as the main factor contributing to their expectations and further influenced the reporting practices among accountants in SIRC. Others are state fatwa (Islamic rulings), audit expectations and individual perceptions. The result of the interviews revealed that on the top of accounting standards and government guidelines on the reporting for all government agencies, SIRC should take into account their greater accountability, which should be reflected in their reporting practices. Therefore, Islamic accountability through fatwa, audit expectations and public demands could be considered. Such awareness is important in SIRC, to differentiate them from other government agencies. The existence of governance similar to the board of members in a company, in SIRC through the fatwa committee. Therefore, this study suggests that the extent and quality of disclosure depends on the demand from the regulators, auditors and funders. The findings suggest that SIRC should have an incentive to provide more information to various stakeholders.
\end{abstract}

Keywords-Disclosure, Islamic finance, accountability, State Islamic Religious Councils.

\section{INTRODUCTION}

$\mathrm{N}$ UMEROUS studies have been undertaken to identify the underlying motives of corporate disclosure. The disclosure practice is subject to the varying target audience and purpose of the report [1]. In particular, identifying the stakeholders and their relationships with reporting entities is important to identifying their different interests [2]. A review of previous studies showed that various interests are based on the political, economic or financial and social factors, institutional and governance mechanisms [3], also explain factors that influence the disclosure practice. Specifically, this paper aims to identify factors that influence the expectations of content of reporting in the SIRC's annual reports.

Rosnia Masruki is with the Faculty of Economics and Muamalat (Business), Universiti Sains Islam Malaysia, Bandar Baru Nilai, 71800 Nilai, Negeri Sembilan, Malaysia (corresponding author's phone: +603-798 6309; e-mail: rosnia@usim.edu.my).

Khaled Hussainey is with the Portsmouth Business School, University of Portsmouth, Portland Street, Portsmouth, PO1 3DE, UK (e-mail: khaled.hussainey@port.ac.uk).

Doaa Aly is with the Business School, University of Gloucestershire, The Park, Cheltenham, GL50 2RH, UK (e-mail:daly@glos.ac.uk) and with Helwan University, Egypt
Next section reviews several motives of disclosure. The remainder of this paper is organised as follows: Section II discusses the research methodology. Section III presents the results and Section IV summarises and concludes.

Five motives of disclosure are discussed, these are: political, financial, social, institutional and governance.

\section{A. Political Motives}

Disclosure in the public sector is heavily based on the application of the principal-agency relationship similar to that in the private sector, which acts to reduce information asymmetry. As a result of information asymmetry in the principal-agency relationship. [4] asserts that cases in developing countries such as corruption, abuse of authority, theft, deceive, patronage and favouritism exist in politics and public administration. Indeed, to reduce this information asymmetry, transparency in the public sector is essential. This may motivate political managers as agents to disclose information that allows the monitoring of their actions [5]. The information is essential for showing accountability of the politicians and honouring their promise for re-election purposes.

[6] found that disclosure levels depend on political competition in Spanish city councils. The higher the political competition, the more likely they are to disclose. However, a study conducted by [5] on local authority in New Zealand failed to support such a consensus. This is similar to [7], a study conducted in the US. The agency theory eventually consistent with the public accountability paradigm which explains the direct relationship between funding and disclosure level [8]. However, the result is mixed since [9] supports the prediction whereas others failed to provide evidence [8] [10].

\section{B. Financial Motives}

Another contributing factor is financial motivations for economic interest. In general, government entities and NPO depend on external and self-funding. Fund-raising issue thus, is crucial to finance their operations. Higher disclosure is provided to signal that the reporting entities have managed their funds wisely, so that it might influence the contribution decision [2]. [11] examined the disclosure level of the 2010 annual report of registered religions NPO (RNPO) in Malaysia. They found that the funded RNPO reported a higher level of disclosure than the non-funded RNPO. Likewise, this was proved by [12], who indicated that managers use the annual report to ensure a continuous flow of resources to their 
organisations. Nevertheless, [13] revealed inconsistent results about whether donors in the US use disclosure information for decisions about donations. As a result, [14] found that the reports for small fund-raising charities are considerably better than for large fund-raising charities.

\section{Social Motives}

Social context includes trust, religion and organisational structure which affect disclosure. [15] conducted interviews with trustees and preparers of annual reports in Muslim charity organisations in the UK. They found that donors absolutely trust Muslim charities based on the 'identity-based trustee' and 'knowledge-based trust' and has resulted in low disclosure. This trust of donors appears to override the need for accounting, which is consequently neglected.

However, [16] assert that accounting may enhance the accountability mechanism in line with the religious spirit [17] [18]. For instance, [17] found that religious organisations are prominent in accounting practice for accountability discharge. Not only religion but also other social contexts such as modernity status and location of regions, exert their influence. States with higher economic activities have better disclosure in comparison with rural and traditional regions.

[19] examined the importance of the annual report, in a different social context within the legitimacy paradigm. They performed a longitudinal single case study of the Department of Conservation (DOC) in New Zealand. They reviewed a Statement of Service Performance in the printed media from its establishment in 1987 to 30 June 2006 through the annual report. It was revealed that the annual report could play an important legitimising role. However, the extent of disclosure in the annual report was ignored.

Despite the importance of the annual report, disclosure that meets the needs of stakeholders is crucial. [20] examined institutional donor expectations and the information that charity management offers to understand the expectation of stakeholders. They performed telephone interviews followed by email. It was found that financial and non-financial information is perceived as important by the institutional donors, but is not the charity's major concern. They have identified expectation gaps between the donors and the charity.

\section{Institutional Motives}

Institutional motivations consist of three factors: namely size, accessibility and staffing profile, which might explain such disclosure practice. Firstly, the size of the reporting entity may explain the extent of disclosure as suggested in the agency theory. Large firms have a higher agency theory encouraging management to disclose more information to mitigate agency conflict. Further arguments are the economies of scale in relation to the cost of gathering, collecting and reporting [5], complexity and a high number of activities which may expect greater disclosure. [20] found that the size is highly significant and positively associated to the extent of disclosure of charities. Such notion also has been proven in [21] study on museums in the US.

Secondly, accessibility is another factor that influences disclosure. With today's rapid ICT development, egovernment is very well-established and the most effective channel of information for the annual report is on website. This offers attractive multimedia features acceptable by the public [22]. There is less cost, wider readership and faster accessibility than traditional publication [23]. [24] examined the usefulness of financial reporting on the website, complementary to the printed annual report. They found that internet reporting is the best communication channel because of its dynamic and unique features using web browser and hyperlinks. This implies that the easier public access to the annual report, the disclosure level in the annual report would be higher. Indeed, the internet may work in justifying the increasing use of reports by government.

Thirdly, staffing profile on the number of staff and their qualifications may explain the extent of disclosure. [25] interviewed representatives of charity organisations in Malaysia to investigate the problems faced in preparing financial reports. It was discovered that although all charity organisations submitted their balance sheets to the Registrar of Society (ROS), the degree of reporting practices vary. Only $60 \%$ of them presented a cash flow statement and 59\% had their financial reports audited by external auditors. This was due to the lack of skilled accounting staff and high staff turnover, which calls for the need to employ experienced accountants. This is supported by [14], he found that accessibility to qualified accountants in large Dutch registered charities is more likely to result in higher quality of reporting than smaller charities. Smaller charities tend to suffer from misreporting and misclassifying due to less monitoring and the sophistication of accounting tasks.

\section{E. Governance Motives}

There are two forms of governance; external and internal, which encourage accountability and transparency. External governance includes accounting rules, requirements of reporting and the government regulations to encourage compliance. Internal governance refers to corporate governance mechanisms such as attributes of board of directors and audit committees in terms of size and composition. These are discussed next in some details.

External governance emphasises regulations, which have been acknowledged in many studies. The absence of accounting guidelines and ineffective enforcement may influence disclosure [20] [26]. The governance may gain trust of stakeholders, and this can be best reflected in the reporting while effective regulation is eventually articulated for legitimation. This is to demonstrate the accountability of reporting entities.

[27] examined the accounting and financial reporting of orphanage in America. It was found that the orphanage recorded the reporting of expenditure and source of funds. They inferred that external reporting may have been legitimising factors to overcome the liability of newness. A sense of propriety and transparency were promoted among the stakeholders, especially contributors. Yet, the study suggests that the effectiveness of regulation is still a significant issue in assuring compliance. This view is consistent with a study in Italy which was conducted by [28], who revealed that regulation is essential as a mechanism to regulate social disclosure practice in Italy. The disclosure practice demonstrates a process of convergence towards a partially 
regulated framework, which requires standards and guidelines. Consequently, it is suggested that reporting standards for the NPO require improvement to increase usefulness [17] [26], to allow accurate judgement on donation decision-making [1].

Pertaining to internal governance, previous studies have shown board size, composition and performance can explain the extent of disclosure. [29] analysed the association between governance, accountability and accounting in the UK local government. The study concluded that there is a relative importance of accountability over governance. The governance aspects had been neglected because the organisations merely focused on conformance. Thus, this indicates the needs of improving corporate governance mechanisms such as board size, composition and audit committee attributes in non-profit based organisations.

\section{METHODOLOGY}

Semi-structured interviews were conducted, augmenting the findings and to address the basis of the disclosure practices. Specifically these investigated the factors that influence the expectations of information disclosure in SIRC annual reports. In this study, the interviews are conducted in Malay (official language in the Malaysian public sector) via Skype. The Skype interviewing is a useful replacement for traditional face-to-face interviews to gain access to interviewees [30]. The majority interviews lasted between 30-45 minutes to a maximum of 60 minutes. The conversations were recorded with the consent of interviewees. This study shows various different perspectives of interviewees in order to gain insights into the SIRC annual reports, thereby representing each stakeholder group. These are preparers (10 accountants of SIRC), regulators (2) and auditors (3 National Auditors) and users $^{1}$ ( 2 fund contributors/academics), asking the preparers and non-preparers: What are the factors that influence the content of reporting in the SIRC's annual reports?

\section{RESULTS}

This section discusses the responses from interviews on what the preparers (AC), auditors (AU), regulators (R) and the public (C) perceived about information disclosure in the SIRC annual reports. This will identify factors that influence the expectations of stakeholders on the disclosure in SIRC annual reports. The findings are discussed according to four themes that were identified in the interview analysis.

\section{A. National Accounting Standards}

In Malaysia, the Malaysian Public Sector Accounting Standard (MPSAS) applies to all public sector entities in Malaysia other than government business enterprises (Accountant General's Department, 2013). When accountants in SIRC were asked about the basis of preparing financial statements, the majority of the answers were accounting standard'. This deals with the most basic accountability level for compliance with the accounting standards [31]. One accountant in the North2 stated: "Accounting standards are

\footnotetext{
${ }^{1}$ The contributors/academics (Professor in Public Sector and Islamic Accounting coded as $\mathrm{C} 1$ and $\mathrm{C} 2$ ), representing the public are considered those who are interested in the SIRC annual reports as funders and knowledgeable.
}

the main guidelines in preparing financial statements" (AC4). Another accountant in EastCoast1 commented: "We follow MFRS" (AC12), while one accountant in EastCoast2 added: "We follow the accounting standards in PERS (private entity reporting standards)" (AC11). Further explanation on PERS, was mentioned by an accountant in the Central2: "We follow accounting standards issued by Malaysian Accounting Standard Board (MASB), specifically PERS because we are a small entity and have no subsidiary" (AC2).

The importance of accounting standards compliance has been highlighted by a National Auditor who stated: "All disclosure items should be disclosed in the annual report of SIRC if they are affected in the financial statements, it should be explained in the notes to the accounts and none of them could be escaped" (AU1). However, due to the uniqueness of SIRC, the accounting standard is not the only consideration in preparing financial statements. A National Auditor pointed out: "Despite the accounting standards, SIRC is also subject to the provisions of state enactment" (AU3). This is because of the existence of monitoring a Shariah committee in every SIRC to ensure Shariah compliance.

One accountant in the South posited: "In terms of reporting, we follow the accounting standards, at the same time considering fatwa which even takes precedence over the standards" (AC9). An accountant in the North supported this by saying: "The accounting standard is one of our guidelines in preparing annual reports and then we take into account any decision being made by fatwa in our council. As our main focus is on zakat, so our main reference is Shariah compliance which takes precedence over the accounting standards. This matter also has been acknowledged by the National Audit Department" (AC4).

This practice was relevant as a national accountant policy maker stated:"Although financial statements are audited based on the accounting standards, some activities in SIRC such as zakat, waqaf and mal are not covered in the accounting standards" (R1). The auditor mentioned: "The SIRC annual report that I audited used best reporting practice in preparing its financial statement. However, if there is a lack of guidelines, the SIRC has to refer to its fatwa committee and it should be accepted by the auditors" (AU1). Another view of one researcher highlighted the lack of accounting standards. "In terms of references that they should refer to, if I'm not mistaken there might be no specific accounting standard in particular in preparing the annual report that SIRC have to follow" (C2).

Due to the complexity of the reporting for SIRC, an accountant in the North said: "We have to fulfil several constituents; these are fatwa, board members and MASB. But in terms of accounting standards, MASB is undergoing research about zakat accounting and they requested data from us for that research purpose" (AC4). As a result, SIRC has a wide accountability chain which has led to different types of accountability aspects, as one researcher claimed: "On the one hand, we have financial accountability and on the other hand we have religious accountability, so there are two aspects of accountability here. It is not just purely administrative and financial; it is also about Islamic accountability" (C1). Another researcher also agreed:"Besides the financial 
accountability, SIRC also need to think of accountability in terms of their management and political accountability" (C2).

In short, three types of accountability that SIRC need to take into account in preparing annual reports, which are: financial, political and managerial [5] [14] [17]. The various types of accountability have led to different interests such as economic, political, legal and social accountability. These factors could influence the reporting content of SIRC in order to satisfy the needs of various stakeholders with different interests. Despite the various challenges in fulfilling several types of accountability to address many constituents, a number of suggestions were highlighted. One researcher recommended: "SIRC are state statutory bodies so, what they can do is to refer to federal statutory bodies requirements because the federal statutory bodies reporting requirements are quite regulated" (C2).

The reporting guideline for preparing the annual report here refers to the Malaysian Government Treasury Circular (MGTC) 4/2007 which was issued by the Ministry of Finance, Malaysia. However, there is a limitation of such a reference, as further explained by the researcher: "Referring to MGTC 4/2007, it is just part of what they should do. SIRC have a different system than the federal statutory bodies but at least they have some references to the established reporting system" (C2). As the circular applies to all statutory bodies in general, not all disclosure items recommended are applicable to SIRC. However, they can take part of the circular and enhance it, based on their own positions and public expectations.

Another key point to highlight from this suggestion is the development of a reporting system. The researcher (C2) posited it should be done collectively, which means that all SIRC representatives sit together. Accountants can consider and deliberate on what the best reporting system should be. Finally, a set of recommendations can be made for the best reporting practices for SIRC, as pointed out by another researcher: "If you follow the development of government financial reporting in Malaysia, it is a basic administrative accountability; they have yet to move to wider stakeholder accountability towards the public. In general, government financial reporting in Malaysia is very fundamental not really reaching the level of what we have seen in the UK, Australia or in the US" $(\mathrm{C} 1)$.

All government entities in Malaysia are audited by the National Audit Department (NAD). SIRC may also be influenced by government financial statement requirements. In this case, however, the need for zakat reporting is crucial in SIRC so as to satisfy the needs of stakeholders within public accountability. This is suggested by $\mathrm{C} 1$ which supports the present study. As such, the present study is pertinent and supported by several interviewees among accountants in SIRC, regulators and researchers.

Apart from developing a reporting system specifically for SIRC, benchmarking might be helpful in the process. The question here is to whom SIRC should benchmark their reporting. Different points of view were obtained from SIRC accountants, researchers and regulators on current reporting practices: "We refer to the corporate annual report, we look at the nature of the information disclosure being disclosed such as structure of organisations, mission and vision but it should be revised based on the SIRC context such as zakat and other funds" (AC3). "SIRC could benchmark their reporting system with similar organisations such as local government. Although SIRC are state statutory bodies, what they can do is to refer to the reporting of federal government, and SIRC could follow any appropriate provision of the reporting since the federal statutory bodies are more regulated in reporting" (C2). This has been supported by regulators: "If we look at the annual report of the federal SIRC, it is more comprehensive" (R3). "...their report is more detailed compared to other SIRC. Probably, it is because they have a huge amount of zakat collection that needs to be reported" (R1).

The high level of voluntary disclosure in SIRC as the zakat collection increases. Meanwhile, accounting standards are believed to be the prime basis for preparing annual reports [26] for SIRC, specifically financial statements as required by the Malaysian National Audit Department (NAD). However, due to the uniqueness of SIRC as not only a government entity, but established within the Islamic setting, they have to have their own reporting system. Developing the best reporting practices for SIRC is believed to resolve such conflict through benchmarking. It could be done with federal statutory bodies and local governments or even other corporate entities, which are more regulated in their reporting systems. In fact, the NAD also acknowledged the uniqueness of SIRC in reporting requirements. Shariah has to be followed via a fatwa committee in each SIRC board respectively.

\section{B. State fatwa (Islamic rulings)}

Since SIRC were established within the Islamic setting, Shariah has to be followed in conducting administration of Muslim wealth. This was agreed by the majority of the respondents, supporting [15] [16]. Apart from the basic administrative accountability in government, there are religious obligations in faith-based organisations [15]. One researcher highlighted "We have financial accountability, as well as religious accountability. So, there are two aspects of accountability here. It is not purely administrative or financial; it is also about Islamic accountability" (C1).

Islamic accountability is appropriate to SIRC because they are held responsible mainly for zakat which is a religious obligation. However, a researcher claimed: “..but treatments by many religious organizations including SIRC are because they are subjected to the government reporting requirements, so they treat pure financial accountability as normal like other government institutions; providing newsletters and so on, to them is good enough" (C1). In essence, the understanding of Islamic accountability suggests the need for annual reports beyond just the mandatory financial statement. Another researcher also pointed out: "...If they don't disclose information, people may have some bad perceptions...things are not difficult to be reported but have high merit to the public Muslims" (C2). This infers the needs of a comprehensive annual report to avoid negative perceptions among stakeholders in discharging SIRC accountability.

As for SIRC, they have a fatwa committee which is led by the mufti of the state. One accountant defined fatwa: "...mufti is one of the board members, and regarding any inquiries raised in the board meeting, the mufti will make the decision and this matter will be put forward to the Department of Fatwa in the state. If there is a financial implication, it will be 
disclosed in the financial statement" (AC6). One regulator explained: "Usually, in the case of financial statements, the fatwa council is not directly involved. However, if it is about zakat and waqaf related matters, fatwa decisions are referred to as provided in the state enactment" (R1). An accountant in the North also agreed the important roles of fatwa: "The role of fatwa is important and we even prioritise any decision made by our state fatwa" (AC7). Indeed, Shariah has been acknowledged by the regulators and accountants as the prime concern in SIRC reporting. Therefore, although accounting standards should be complied with, should any conflicts between accounting standards and fatwa arise, the latter should take precedence.

\section{Audit expectations}

Auditing for SIRC is an annual routine task which is carried out by the State National Audit Department (NAD) similar to that at federal level. The audit is performed to examine the financial statements of SIRC, whether it is presented in a true and fair view as provided in the Audit Act 1957. One National Auditor highlighted: "A main duty of an auditor is to validate the financial statement including receivable and payable accounts. They are audited against the approved budget and accounting standards" (AUD3). She added that only the financial statement is audited. However, usually information other than that provided in the financial statement is requested, such as activity reports for the audit purpose. Such financial statement concerns on the notes to the accounts, which explain details of the presented accounts such as the operations and activities. Yet, is not as comprehensive as the annual report.

This indicates that the preparation of annual reports is encouraged, to explain the collection and spending of funds of the year [2]. Further explanation about the post-audit work was elaborated by another auditor: "In practice, after the audit certificate has been issued by the National Audit Department $(N A D)$, it will be presented in the State Assembly, subject to the provision in the State enactment. The state government ought to prepare documentation to the State Secretary of Government including an annual report, if there is enforcement to present it like the Federal Territory. We will only audit the annual report, if it is provided in the state enactment. Other documents such as the minutes of meetings and the accountability index also are used in auditing" (AU2). The pre-determined audit checklist of the financial statement is identified based on the accounting standards, audit requirements and other related documents for compliance. However, a comprehensive annual report is also suggested to better explain the SIRC activities. All of them are subject to the state enactment and fatwa in the respective SIRC. Consequently, this might influence the SIRC reporting practices regarding accountability for legality and probity.

\section{Individual Perceptions}

Perception is another factor that influences the expectations of information disclosure and the current reporting practices, including issues in relation to the accountability relationship between the stakeholders and SIRC, the attitude of the public and top management, are elaborated here. This study views the entire stakeholder groups comprehensively within the purview of public accountability.
The meaning of SIRC stakeholders was defined by a researcher to identify the accountability relationship and information disclosure issue in relation to SIRC: "To me, whatever information that they should disclose or decide to disclose, should be based on a few things. One of them is what is their accountability to stakeholders? Stakeholders mean the Muslim public. So, they have to identify what the needs of the Muslim public are in terms of information they would like, about the organization, their accountability and transparency" (C2). Two key findings from the above quotations are: the Muslim public are the stakeholders of SIRC, and their needs are crucial to identify to what extent information of the SIRC, is held accountable to the stakeholders. In order to disseminate the information to the stakeholders, those responses suggest an annual report is needed to mitigate conflict in the agency and stakeholder theories. The importance of an annual report was claimed by another researcher: "I strongly agree that an annual report is prepared by SIRC for the simple reason that the demand for accountability by stakeholders is actually a very direct relationship, because they are zakat payers. I think the contribution to SIRC in the financial contribution makes the bulletin and newsletters insufficient to many educated and enlightened zakat payers nowadays" (C1).

Another accountability chain which emerges is between the SIRC and its state government. Contribution from the state government was mentioned by an accountant in East Coast1 (AC12). Apart from the zakat collection, being a recipient of a grant from government, SIRC are also accountable to the government. They should consider government expectation in identifying items of disclosure beyond the compliance of a financial statement. An annual report is suggested in addition to the financial statements as claimed by a researcher: "...because of the simple accountability relationship between SIRC and the contributors, so far, the only mechanism to SIRC to be seen as accountable is through the publication of newsletters, brochures and so on. However, the contributors now are more educated, they are more sophisticated. Many times we heard about the dissatisfaction especially in the zakat payers" (C1). The reasons for dissatisfaction were highlighted: "...for example the way SIRC distribute zakat because they want to know more about the distribution, they want to know more about the financial management of zakat institution so... yet it's not actually well met by SIRC in Malaysia so far" (Cl).

This shows that the fund contributors are demanding to know the break down figures and explanations about the distribution funds, indicating that SIRC are accountable to the funders. Otherwise, this forces them to make inquiries, complaints and voice their dissatisfactions about SIRC [32]. The routine circulation of bulletins and newsletters nowadays, is not sufficient for those who are more aware of the roles of SIRC and their accountability. In this scenario, one accountant (AC7) in North3 highlighted that fund contributors do not know the details about fund collection and distribution for the current year. Thus, she suggested that a performance measurement should be included in today's annual report to explain to those curious members of the public. Another suggestion in a purview of public accountability was elaborated: "The element of public accountability is where we 
have to identify our potential stakeholders. Now, we have to start with the needs of the stakeholders and then, we have to move backward. What are the needs of the stakeholders?" (C1). Indeed, this study aims to discover the information needs of stakeholders.

An accountant in SIRC (AC3) mentioned that a board council of SIRC consists of state government Islamic scholars (mufti) and is responsible for any Islamic matters raised in the SIRC as provided in the state enactment. Therefore, this study suggests that a wide range of stakeholders have different interest on the information disclosure from SIRC, supporting the interest in political, financial and social.

\section{CONCLUSION}

This study involved interviews with SIRC accountants, policy makers and users, such as auditors and the public, in response to the research objective i.e. to answer: What are the factors affecting the expectations and current practices of disclosure in the SIRC's annual reports? Most respondents agreed that the main basis for disclosure in SIRC was accounting standards, decisions of State fatwa and expectations of both audit and individual perceptions. Based on these findings, several factors could not be explained in the previous quantitative studies but were highlighted in the interviews. Therefore, the present interview findings complemented the quantitative results in previous disclosure studies. Future studies might consider to include corporate governance practice, as board of directors is responsible to manage the disclosure of information.

\section{REFERENCES}

[1] Ntim, C. G., Soobaroyen, T., \& Broad, M. J. (2016). Governance structures, Voluntary disclosures and public accountability: The case of UK Higher Education Institutions. Accounting, Auditing and Accountability Journal, 44.

[2] Connolly, C., \& Hyndman, N. (2004). Performance reporting: a comparative study of British and Irish charities. The British Accounting Review, 36(2), 127-154.

https://doi.org/10.1016/j.bar.2003.10.004

[3] Bakar, N. B. A., \& Saleh, Z. (2011b). Incentives for Disclosure of Accounting Information in Public Sector: A Literature Survey. International Research Journal of Finance and Economics, (75).

[4] Sarker, A. E. (2006). New public management in developing countries: An analysis of success and failure with particular reference to Singapore and Bangladesh. International Journal of Public Sector Management, 19(2), 180-203.

https://doi.org/10.1108/09513550610650437

[5] Laswad, F., Fisher, R., \& Oyelere, P. (2005). Determinants of voluntary Internet financial reporting by local government authorities. Journal of Accounting and Public Policy, 24(2), 101-121.

https://doi.org/10.1016/j.jaccpubpol.2004.12.006

[6] Gandía, J. L., \& Archidona, M. C. (2008). Determinants of web site information by Spanish city councils. Online Information Review, 32(1), $35-57$. https://doi.org/10.1108/14684520810865976

[7] Evans, J. H., \& Patton, J. M. (1987). Signaling and Monitoring in Public-Sector Accounting. Journal of Accounting Research, 25, 130159. https://doi.org/10.2307/2491083

[8] Bakar, N. B. A., \& Saleh, Z. (2011a). Disclosure of accountability information in public sector: The case of Malaysian Federal Statutory Bodies. In 13th Biennial CIGAR Conference: Bridging public sector and non-profit sector accounting (pp. 1-38). Ghent.

[9] Ingram (1984)M. Young, The Techincal Writers Handbook. Mill Valley, CA: University Science, 1989.
[10] Robbins, W. A., \& Austin, K. R. (1986). Disclosure Quality in Governmental Financial Reports: An Assessment of the Appropriateness of a Compound Measure. Journal of Accounting Research, 24(2), 412-421

https://doi.org/10.2307/2491145

[11] Atan, R., Zainon, S., Nam, R. Y. T., \& Aliman, S. (2012). Analyzing Disclosure Practice of Religious Nonprofit Organizations using Partial Disclosure Index. World Academy of Science, Engineering and Technology, 68, 1389-1395.

[12] Arshad, R., Bakar, N. A., Sakri, F. H., \& Omar, N. (2013). Organizational Characteristics and Disclosure Practices of Non-profit Organizations in Malaysia. Asian Social Science, 9(1), 209-217.

[13] Parsons, L. M. (2007). The Impact of Financial Information and Voluntary Disclosures on Contributions to Not-For-Profit Organisations. Behavioural Research in Accounting, 19, 179-196. https://doi.org/10.2308/bria.2007.19.1.179

[14] Heijden, H. Van Der. (2013). Small is beautiful? Financial efficiency of small fundraising charities. The British Accounting Review, 45(1), 5057. https://doi.org/10.1016/j.bar.2012.12.004

[15] Yasmin, S., Haniffa, R., \& Hudaib, M. (2014). Communicated accountability by faith-based charity organisations. Journal of Business Ethics, 122(1), 103-123. https://doi.org/10.1007/s10551-013-1759-2

[16] Jayasinghe, K., \& Soobaroyen, T. (2009). Religious "spirit" and peoples' perceptions of accountability in Hindu and Buddhist religious organizations. Accounting, Auditing \& Accountability Journal, 22(7), 997-1028 https://doi.org/10.1108/09513570910987358

[17] Abdul-Rahman, A. R. (1998). Issues in Corporate Accountability and Governance: An Islamic Perspective. American Journal of Islamic Social Sciences, 15(1), 55-69.

[18] Abdul-Rahman, A. R. (1998). Issues in Corporate Accountability and Governance: An Islamic Perspective. American Journal of Islamic Social Sciences, 15(1), 55-69.

[19] Samkin, G., \& Schneider, A. (2010). Accountability, narrative reporting and legitimation: The case of a New Zealand public benefit entity. Accounting, Auditing \& Accountability Journal, 23(2), 256-289. https://doi.org/10.1108/09513571011023219

[20] Zainon, S., Atan, R., Wah, Y. B., \& Nam, R. Y. T. (2011). Institutional donors' expectation of information from the non-profit organizations (NPOs) reporting: A pilot survey. International NGO Journal, 6(8), $170-180$.

[21] Christensen, A. L., \& Mohr, R. M. (2003). Not-for-profit annual reports: What do museum managers communicate? Financial Accountability \& Management, 19(2), 139-159.

https://doi.org/10.1111/1468-0408.00167

[22] Fisher, E. (2004). The European Union in the Age of Accountability. Oxford Journal of Legal Studies, 24(3), 495-515. https://doi.org/10.1093/ojls/24.3.495

[23] Debreceny, R., Gray, G. L., \& Rahman, A. (2002). The determinants of Internet financial reporting. Journal of Accounting and Public Policy, 21(4-5), 371-394. https://doi.org/10.1016/S0278-4254(02)00067-4

[24] Ashbaugh, H., Johnstone, K. M., \& Warfield, T. D. (1999). Corporate Reporting on the Internet. American Accounting Association, 13(3), 241-257.

https://doi.org/10.2308/acch.1999.13.3.241

[25] Nasir, N. M., Othman, R., Said, J., \& Ghani, E. K. (2009). Financial Reporting Practices of Charity Organisations: A Malaysian Evidence. International Bulletin of Business Administration, (6), 19-27.

[26] Dhanani, A., \& Connolly, C. (2012). Discharging not-for-profit accountability: UK charities and public discourse. Accounting, Auditing \& Accountability Journal, 25(7), 1140-1169. https://doi.org/10.1108/09513571211263220

[27] Daniels, R. B., Braswell, M., \& Beeler, J. D. (2010). Accounting and Financial Reporting by a Late 18th Century American Charity. Accounting Historians Journal, 37(2), 39-65.

[28] Mussari, R., \& Monfardini, P. (2010). Practices of Social Reporting in Public Sector and Non-profit Organizations. Public Management Review, 12(4), 487-492.

https://doi.org/10.1080/14719037.2010.496262 
[29] Goddard, A. (2005). Accounting and NPM in UK Local Government Contributions Towards Governance and Accountability. Financial Accountability and Management, 21(2), 191-218.

https://doi.org/10.1111/j.1468-0408.2005.00215.x

[30] Deakin, H., \& Wakefield, K. (2014). Skype interviewing: Reflections of two PhD researchers. Qualitative Research, 14(5), 603-616.. https://doi.org/10.1177/1468794113488126

[31] Dunne, T. (2013). Governance and performance reporting in Scottish charities. Journal of Financial Reporting and Accounting, 11(2), 112130.

https://doi.org/10.1108/JFRA-11-2011-0015

[32] Wahid, H., Ahmad, S., \& Kader, R. A. (2009). Pengagihan zakat oleh institusi zakat di Malaysia: Mengapa masyarakat Islam tidak berpuas hati? Jurnal Syariah, 17(1), 89-112. 